\title{
Principles of Management Application in Building Construction Projects: Perspectives of Project Managers'
}

\author{
Dorcas Omolola Adeagbo ${ }^{1}$, Sani Mohammed ${ }^{2}$, Sani Abdulkadir ${ }^{2}$
}

${ }^{1}$ University of Jos, Department of Building

Bauchi Road, Jos, Nigeria

${ }^{2}$ Abubakar Tafawa Balewa University, Department of Building

Tafawa Balewa Way, P. M. B. 0248, Bauchi, 740272, Nigeria

DOI: $10.22178 /$ pos.53-7

JEL Classification: M14

Received 30.11.2019

Accepted 28.12.2019

Published online 31.12.2019

Corresponding Author:

Sani Abdulkadir

arabs4u@gmail.com

\begin{abstract}
One of the most crucial factors to consider when setting up and managing organizational activities is the application of management principles. Most of the time, organizational failure is attributed to either as a violation of management principles or an organization's inability to establish this precedent in the running of its day-to-day activities. This paper, therefore, focused on the application of the management principles of Henri Fayol in the management of human resources for construction projects. The study utilized a descriptive design using a survey study and explorative design through a literature search. Relevant literature was reviewed to identify management principles for the design of the questionnaire. The population is the core building professionals working as project managers in a construction site of three tertiary institutions in Bauchi. Forty-five (45) questionnaires were distributed and successfully filled and retrieved. SPSS software was used for the analysis. The study used descriptive statistics and the Kruskal-Wallis test for the analysis. The results show that the majority of the respondents $(80 \%)$ acknowledged the importance of these principles to the construction industry in the management of human resources in the construction site. Also, the findings revealed that project managers always used most of these principles in the management of human resources in the construction site. Although, lack of planning and motivation, non-adherence to principles and standards, clashes of interest and corruption revealed as top challenges of its implementation on construction site. The finding concludes that the more the respondent works longer on construction sites, the higher the application of these principles in managing human resources on sites.
\end{abstract}

(C) 2019 The Authors. This article
is licensed under a Creative

Commons Attribution 4.0 License (c) (1)

Keywords: Henry Fayol; Human Resource; Management Principles; Construction and Project Managers.

\section{INTRODUCTION}

Management principles are propositions established by various scholars based on fundamental facts. The principles serve as a guide for decisionmaking, planning and management action [10, 2]. Management skills are needed to improve the performance of an organization in construction projects, and these activities involve many activities involving more people as a team working towards achieving organizational goals and objectives [3]. These principles are established through observations, practice and long-term management experience. Authors [6] claimed that the main goals of an organization's management principle are to improve the working condition, which will increase efficiency by saving costs and improving profit. However, the problem is how to extend the theories of management principles into practice. This paper aims to assess the extent of the application of principles of management in the management of human resources in construction projects. The objectives of the study are: To assess the stakeholders' perception about the relevancy of Henry Fayol principles of management application in construction industry, to determine the extent of usage of Henry Fayol management principles by project managers in building construction projects and to identify the challenges in implementation of Henry Fayol management principles on construction sites. 
Henry Fayol's principles of management. Druker claims that one learns by doing so [7]. Does he argue that the manager's first task is to define what our business is? The answer to this question is also going to lead to another question about what to do? When is there to be done? What and who is it necessary to do this? Moreover, how do you make sure it's done? Because of his management experience, Henri Fayol was able to synthesize fourteen (14) management principles [10]. The principles for successful management are expected to guide managers toward the establishment and management of an organization:

Division of work. Labor division and specialization increase productivity by promoting accuracy, speed, and innovation in the execution of responsibilities [10]. It is expected that the implementation of the labor division will pass through skilled and unskilled labor. This principle is particularly visible in the technical section of the construction company. A lot of skilled and unskilled work is part of a unique and distinct profession. According to specialization, division of labor is therefore performed. Some of the technical section examples of these works include carpentry, masonry, plumbing, electrical work, etc. Within these vast activities, many people have become specialists. Work division may also be a guide in setting up an organizational structure.

Principle of authority. Delegation of power and responsibility is important to get things done. Responsibility must be assigned to employees, and management must give authority to those responsible. Responsibility and authority go hand-in-hand. Whoever has a responsibility at the same time has been given authority on that particular task to be performed. Therefore, the performance of every task will be traced based on assigning responsibilities and authorities. Each section in the construction firm has a head that has the power to give the command. According to [9] the authority principle suggests that managers and other heads of various sections in an organization should be empowered to give their subordinates command. For example, the head of the carpentry section should have the power to assign responsibility to the workers who are directly under his section.

Discipline. Discipline as part of the core management principles deals with obedience, good con- duct and respectful interaction among employees. It is a discipline that allows an employee to abide by the general rules and regulations that guide the running of an organization. It also gives consciousness to the employee to do the right things at the right time. Discipline allows employees to have good and respectful interaction with their colleagues, thereby ensuring the smooth running of the organization. In fact, in managing and organizing, it is the lubricant that removes friction and enhances productivity. Authors [2] think that penalties and penalties for negative action should be made available as part of an organization's rules and regulations. Defaulters should appear before a disciplinary committee depending on the degree of misconduct. For example, delay or poor workmanship can lead to financial loss to the contractor in construction work. Therefore, it was suggested that the deduction of default wages can serve as punishment.

Unity of command. Unity of command requires an employee to receive a command from a single authority. This management principle is all about concentration and unity, and it means that the whole organization should move in the right direction to a common goal and it is important if all employees of a company are to have one vision [5]. According to [10] given employee command by more than one employee-manager may result in mistakes and conflicts of interest that will subsequently affect productivity. The command line management should be one and only one. For example, each employee should receive a command from one person (i.e. his boss) in construction work. Even if the command originates from the higher authority, it must pass through the relevant subordinate.

Unity of direction. Unity of direction as one of the management principles required that every employee's various efforts should be focused and focused on achieving the organization's goals. It is management's responsibility to plan, coordinate and control the various responsibilities of every employee to target organizational goals. Author [7] reported that Management by Object (MBO) is one of the Drucker's organizational concept. This concept is related to the unity of the directive principle of Fayol. It is necessary to give each employee a specific goal to achieve. And the sum of individual employees' effort must be geared towards achieving the organization's 
overall goals. For example, in construction work, the individual employee's effort must be aimed at meeting time, cost, quality and customer satisfaction.

Subordinate of individual interest to organisational interest. Every employee has his interest, including the manager. But the interest of the organization should supersede any other personal interest for the organization to function effectively. The focus is primarily on organizational goals and not on individual objectives. In other words, it says that employees should surrender their interests before the organization's general interest [1] in the same vein [2] believe that employees need to sacrifice their interests for the benefit of the organization. Fall, therefore, indicated that the organization's interest should always be superior to any other personal interest.

Remuneration. Remuneration is one of the ingredients of motivation that is believed to have a direct effect on labor productivity. The remuneration should be reasonable and timely to keep an employee motivated and productive. The salary should also be justifiable, and there should be no short change for the staff [9].

The degree of centralisation. In terms of decisionmaking, centralization in management principles refers to the concentration of authority at the management level [10]. This is in contrast to middle and lower management decentralization of authority. The centralization of authority depends on the size of the organization. Therefore, an organization should strive for and strike a balance on this.

Scalar chain. There should be a command hierarchy in each organization that is represented by the line of authority from top management to the lowest. The authority chain should specify communication means and superior-subordinate relationships [10]. As an organizational chart, the principle of the scalar chain is practice. This principle is always found in Construction Company.

Order. The working environment in an organization should betide, clean and safe. Employees should get whatever they may need to fulfill their responsibilities conveniently. Things should be kept right at the right time and place [10]. This will motivate employees to diligently fulfilled their responsibilities and improve productivity. Construction work requires timely material delivery. Delay in the supply of material may affect the progress of the work that will affect the project's timely completion.

Equity. Equity as one of the management principles requires that employees be treated fairly and impartially. This should be one of the cardinal values of running an organization. Employees should be considered equal before an organization's rules and regulations. There will be equity, fairness, and justice [10].

Stability of tenure of personnel. The stability of staff tenure will foster specialization and increase productivity. In some cases, frequent changes in the position of the employee will destabilize the system and take time to familiarize the employee with the new job [10]. This will waste time and result in low productivity. Experience is one of the most important resources in construction work and construction management activities. Through long practice, this experience is achieved. Therefore, tenure stability and long-term staff tenure will help them gain the experience they need to be able to deliver effectively.

Initiative. Employees should be encouraged to develop new ideas that add value to the output of the organization. In some areas, they should be allowed to express their initiatives that will improve the competence of the organization [10]. In initiating and implementing new ideas, a good manager should be creative [9]. Organization management should provide incentives to encourage productivity.

Esprit de corps. This is a French phrase that means a group of people's enthusiasm and devotion [9]. An organization's management should foster mutual understanding and trust between employees. Through effective communication, this will be achieved. For an organization to achieve the best result, there should be a unified and effective integration and coordination of both individual and group effort. However, unity is the strength of this principle.

\section{METHODOLOGY}

The study utilized a descriptive design using a survey study and explorative design through a literature search. Descriptive research portrays an accurate profile of persons, events or situations [4] while explorative design involves a search of literature that is relevant to the objec- 
tives and provides qualitative information on developmental issues on a view [4]. The study area is the Bauchi States targeting tertiary institution projects. It was chosen because of the high rates of construction activities with a high number of construction professionals [8]. The population is the core building professionals working as project managers in the construction sites, this group was chosen because of their significance in terms of executing of construction works, and they are involved almost in all day-to-day activities of construction works on sites. Therefore, they deemed the best groups to fulfill the objectives of this study. A total of fifteen (15) contractors that are currently on-site work were identified within ATBU, Federal Polytechnic, and State Polytechnic Bauchi. Also, three (3) professionals were selected within the construction sites making a total of 45 respondents for the study. The study used questionnaire as an instrument in collecting data from the respondents and convenience sampling techniques used in distributing the questionnaire to the respondents. This study used descriptive statistics such as frequency, charts and mean. Furthermore, the KruskalWallis test was used to checks for differences among respondents on the extent of application of management principles of Henry Fayol within the study area.

\section{RESULTS AND DISCUSSION}

Demographic background of the respondents. The study depicts the characteristics profiles of the respondent and the results show that the majority of the respondents obtained qualification at postgraduate levels. The construction managers have at least 6 years working experience within the construction industry. Also, Builders constitutes the majority among the respondents and more than $50 \%$ of respondent have years of experience above 5 years as shown in Table 1 below. These imply that the respondents' knowledge and years of experience on construction sites attained a satisfactory level to give a proper verdict on the study.

Stakeholders' Perception about Important of Henry Fayol Management Principles. The first objective aimed at assessing the perception of project managers on the importance of Henry Fayol principles of management in building projects. The questionnaire used in retrieving data to achieve the objectives as formulated, the respon- dents were asked to indicated perception on the important level of these principles using a fivepoint Likert scale from Very important (5) to Not important (1). From the analysis shows that the respondent acknowledged the importance of these principles as relating to construction management on sites with more than $80 \%$ of the respondent representing about 40 respondent indicates at least positive important level which indicates that, these principles are useful on day to day activities of building construction projects as shown in the chart below (Figure 1).

Table 1 - Demographic Information of Respondents

\begin{tabular}{|l|c|c|}
\hline \multicolumn{3}{|c|}{ Qualification of respondents } \\
\hline & Frequency & Percent (\%) \\
\hline Ph. D & 3 & 6.7 \\
\hline MSC & 27 & 60.0 \\
\hline PGD & 3 & 6.7 \\
\hline BSC & 6 & 13.3 \\
\hline HND & 6 & 13.3 \\
\hline Total & 45 & 100.0 \\
\hline \multicolumn{3}{|c|}{ Professions of respondents } \\
\hline Architects & 6 & 13.3 \\
\hline Builders & 24 & 53.3 \\
\hline Quantity Surveyors & 9 & 20.0 \\
\hline Civil Engineer & 6 & 13.3 \\
\hline Total & 45 & 100.0 \\
\hline \multicolumn{2}{|c|}{ Years of experience of respondents } \\
\hline Over 10 years & 12 & 26.7 \\
\hline 6-10 years & 24 & 53.3 \\
\hline 1-5 years & 9 & 20.0 \\
\hline Total & 45 & 100.0 \\
\hline
\end{tabular}

Table 2 shows details' analysis on the level of application of Henry Fayol principles of management in building projects as perceived by the respondents with the weighted mean ranges of (3.8667-3.000). To determine the levels of its application in building projects by the respondents, the following mean calibration was adapted to help for decision-based on the mean value obtained in the result as shown in Table 2.

Referring to Table 2, the results revealed that all the respondents' assessments were above a scored of three in the five points Likert scale. These imply that the respondent agreed and acknowledge its usage or application in building construction projects within the study area. The topmost commonly applied principles are Division of work (MS=3.8667), Interest of organiza- 
tion ahead of others. (MS=3.8000), Teamwork (MS=3.7333), Delegation of power and responsibility (MS=3.6667) and Command hierarchy (MS=3.6667) respectively. This finding implies that, while managing construction sites, the con- struction managers do apply at least one of these principles in building construction projects and the implementation attained a satisfactory level in the construction industry.

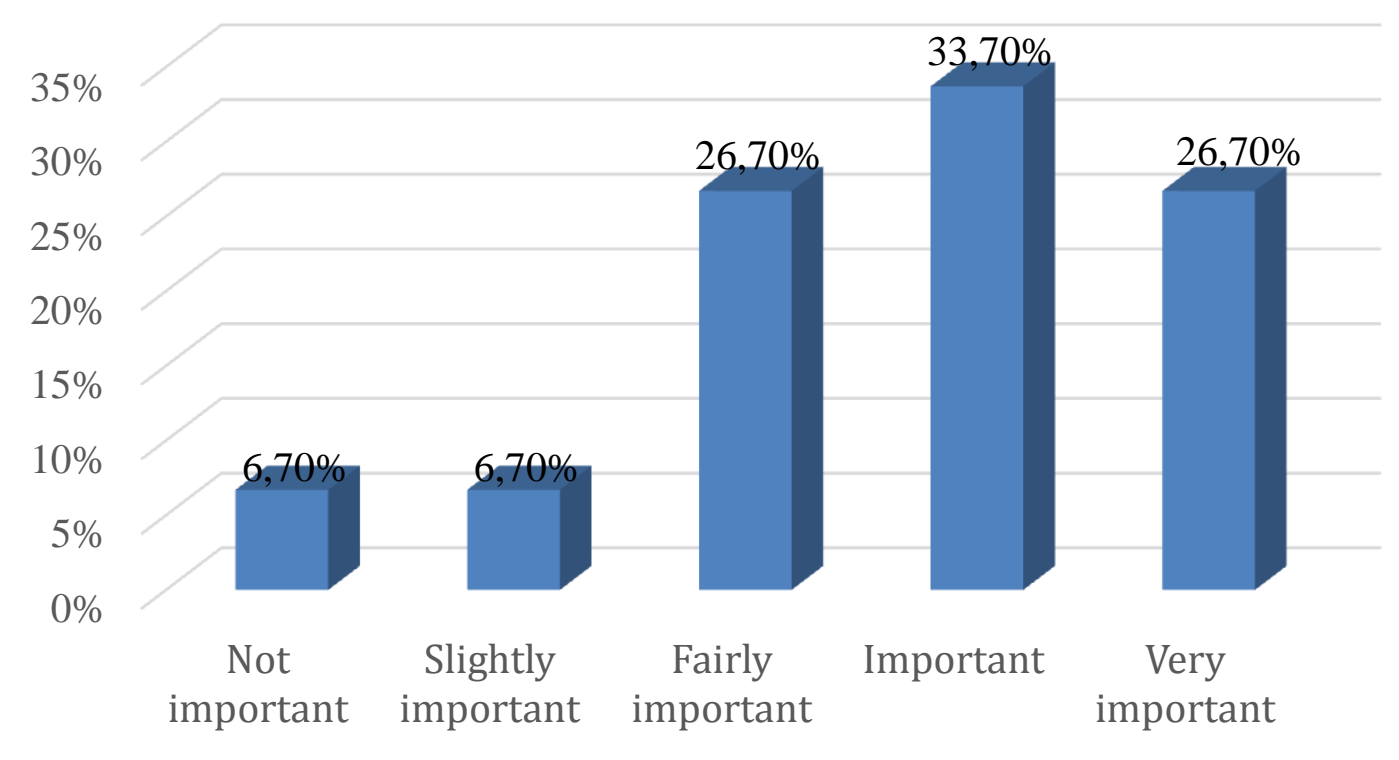

Level of important assessment

Figure 1 - Application of Henry Fayol Management Principles on Construction Sites

Furthermore, a Kruskal-Wallis-Test conducted to determine whether there is a significant difference in the extent of application of these principles by construction manager along years of experience on construction sites of building projects. Referring to Table 2, a Kruskal-Wallis-Test conducted to compare the respondents' perception differences on the level of application of henry fall management principles on sites. The result shows that; the respondent significantly differs on the application of $50 \%$ principles of management as their values are lower than the specified $p v=0.05$ these might be due to years of experience on sites. Also, the results show that the other $50 \%$ principles values are greater than the specified value of 0.05 which indicates that there is no evidence to show that the perception of respondents significantly differs along the years of experience of the respondents. The implication of these finding vindicates that, the more the respondent work longer on construc- tion sites the higher the application of these principles in building construction projects.

Challenges in Implementation of Henry Fayol Management Principles on Sites. The third objective of this study was to identify the challenges of respondents on the application of Henry Fayol's management principles on construction sites within the study area. To achieve this objective, the respondents were asked to indicate in the questionnaires using open-ended questions the challenges confronting the implementation of these management principles on building construction sites. After sorting out the common and repeated challenges as indicated by the respondents, the study was able to identify the top challenges as indicated by the respondents as follows: Corruption; Non-adherence to principles and standards; Clashes of interest in an organization; Different background/upbringing of workers; Lack of motivation and planning. 
Table 2 - Levels of application of Henry Fayol management principles in construction sites

\begin{tabular}{|l|c|c|c|c|c|}
\hline & \multicolumn{3}{|c|}{ Descriptive statistics } & \multicolumn{2}{c|}{ Kruskal-Wallis Test } \\
\hline Principles of Managements & Sum & Mean & Level of application & Chi-square & Sign. @0.05 \\
\hline Division of Work & 174.00 & 3.8667 & Very often & 3.713 & 0.156 \\
\hline Delegation of Power and Responsibility & 165.00 & 3.6667 & Very often & 11.253 & $0.004^{* *}$ \\
\hline Discipline & 153.00 & 3.4000 & Sometimes & 5.372 & 0.068 \\
\hline Unity of Direction to achieve organisation goal & 150.00 & 3.3333 & Sometimes & 13.058 & $0.001^{* *}$ \\
\hline Unity of Command from single authority & 161.00 & 3.5778 & Very often & 7.642 & $0.022^{* *}$ \\
\hline Interest of Organization to be above other interest & 171.00 & 3.8000 & Very often & 2.526 & 0.283 \\
\hline Remunerations and Motivation of staff & 138.00 & 3.0667 & Sometimes & 13.731 & $0.001^{* *}$ \\
\hline Centralization in Terms of Decision-Making & 147.00 & 3.2667 & Sometimes & 9.001 & $0.011^{* *}$ \\
\hline Command Hierarchy & 165.00 & 3.6667 & Very often & 10.368 & $0.006^{* *}$ \\
\hline Tide, Clean and Safe Working Environment & 156.00 & 3.4667 & Sometimes & 3.773 & 0.152 \\
\hline Equity Fair and justice to all & 162.00 & 3.6000 & Very often & 2.879 & 0.237 \\
\hline Stability of Tenure of Personnel & 135.00 & 3.0000 & Sometimes & 3.371 & 0.185 \\
\hline Initiative to Develop New Idea & 147.00 & 3.2667 & Sometimes & 5.470 & 0.065 \\
\hline Team work to achieves client objectives & 168.00 & 3.7333 & Very often & 8.395 & $0.015^{* *}$ \\
\hline
\end{tabular}

Notes: Hardly ever (1.00 to 1.49$)$, Rarely (1.50 to 2.49$)$, Sometimes (2.50 to 3.49$)$, Very often (3.50 to 4.49), Almost always (4.50 to 5.00).

$\star \star$ - Significant perception difference along experience of the respondents

\section{CONCLUSIONS AND RECOMMENDATION}

This paper discusses the application of management principles in the management of human resources in the construction site. While managing construction sites, the construction managers do apply these principles in building construction projects, and the implementation attained a satisfactory level in the construction industry. Furthermore, the higher the years of experience on construction sites the higher the application of these principles in building construction projects.
Although there are some challenges of clashes of interest in a construction site, the principles were found to be relevant and useful in the management of human resources in the construction site. Therefore, the study recommends the professionals within the construction industry actively implement these principles of management while executing construction projects as it proves to be significantly important in attaining the client's predetermined objective.

\section{REFERENCES}

1. Fundamental Principles of Workforce Management. (2017). Construction Site Management and Labor Productivity Improvement, 155-189. doi: 10.1061/9780784414651.ch07

2. Godwin, A., Handsome, O., Ayomide, W., Enobong, A., \& Johnson, F. (2017). Application of the Henri Fayol Principles of Management in Startup Organizations. Journal of Business and Management, 19(10), 78-85.

3. Kehinde, O., Afolabi, O., Omogbolahan, I. (2017). Evaluation of the effect of project management techniques on road construction projects in Nigeria. European Project Management Journal, 7(1), 3-12.

4. Kothari, C., \& Garg, G. (2019). Research Methodology: methods and techniques (4th ed.). New Delhi: New Age International (P) Limited Publishers.

5. Mbalamula, Y., Suru, M., \& Seni, A. (2017). Utility of Henri Fayol's Fourteen Principles in the Administration Process of Secondary Schools in Tanzania. International Journal of Education and Research, 5(6), 103-116.

6. Pokhriyal, S., \& Prasad, M. (2014). Management theories: principles and practices. Journal of Management \& Research, 8(2/4), 1-6 
7. Shaker, A. (2003). The Practice of Management: Reflections on Peter F. Drucker's Landmark book. Academy of Management Perspectives, 17(3), 16-23. doi: 10.5465/ame.2003.10954670

8. Usman, N., Inuwa, I., \& Iro, A. (2012). The Influence of Unethical Professional Practices on the Management of Construction Projects in North Eastern Sates of Nigeria. International Journal of Economics Development Research and Investment, 3(2), 124-129.

9. Uzuegbu, C., \& Nnadozie, C. (2015). Henry Fayol's 14 Principles of Management: Implications for Libraries and Information Centres. Journal of Information Science Theory and Practice, 3(8), 5872. doi: 10.1633/jistap.2015.3.2.5

10. Vliet, V. (2009). 14 Principles of Management (Fayol). Retrieved from

https://www.toolshero.com/management/14-principles-of-management 